\title{
Pendampingan Peningkatan Literasi Baca Tulis Anak Usia Sekolah Di Kelurahan Suprau Distrik Maladum Mes
}

\author{
Vina N. Van Harling1, Sonny Rumalutur ${ }^{2}$, Markus Dwiyanto Tobi ${ }^{3}$ \\ ${ }^{1}$ Program Studi Teknik Mesin, Politeknik Saint Paul Sorong \\ ${ }^{2,3}$ Program Studi Teknik Elektro, Politeknik Saint Paul Sorong \\ E-mail: vina.nathalia@poltekstpaul.ac.id ${ }^{1}$, sonny_r@poltekstpaul.ac.id ${ }^{2}$, \\ dwiyanto@poltekstpaul.ac.id ${ }^{3}$
}

\begin{abstract}
ABSTRAK
Taman Kanak - kanak merupakan Pendidikan awal untuk pengembangan kemampuan literasi anak, karena di sini anak akan diberikan kegiatan menstimulasi perkembangan kemampuan mendengar, berbicara, membaca dan menulis. Sehingga permasalahan yang dimiliki oleh mitra saat ini adalah bagaimana mitra meningkatkan literasi baca dan tulis bagi anak - anak usia 4 6 tahun. Tujuan dari pengabdian ini adalah untuk meningkatkan literasi baca tulis anak usia sekolah di kelurahan Suprau distrik Maladum Mes. Pengabdian dilakukan di Kelurahan Suprau Distrik Maladum Mes dilaksanakan pada bulan Maret - Juni 2020. Metode pelaksanaan yang dilakukan dalam pengabdian ini berupa metode observasi, sosialisasi, dan pendampingan dan evaluasi. Hasil yang diperoleh dari program literasi baca tulis anak - anak usia sekolah ini adalah meningkatnya kemampuan membaca dan kemampuan menulis anak.
\end{abstract}

Kata Kunci: Literasi, membaca, menulis

\section{PENDAHULUAN}

Literasi dan membaca adalah tujuan terpenting Pendidikan nasional bukan hanya untuk anak - anak tetapi juga untuk setiap orang. Karena sejatinya Pendidikan harusnya dapat membebaskan kita dari keterbelakangan, tetapi pada kenyataannya hingga dengan saat ini masih banyak masyarakat yang tidak dapat merasakan Pendidikan itu sendiri.

Kota Sorong merupakan satu - satunya kota yang ada di Provinsi Papua Barat. Menjadi satu - satunya kota bukan berarti kota Sorong termasuk dalam daerah yang memiliki sebaran Pendidikan yang merata. Berdasarkan data BPS kota Sorong tahun 2020, Angka Partisipasi Sekolah (APS) pada tahun 2019 mengalami penurunan pada semua level Pendidikan wajib belajar 9 tahun. Sementara Angka Partisipasi Murni (APM) yang digunakan untuk mengukur tingkat partisipasi penduduk dengan usia yang sesuai dengan sekolah pada jenjang Pendidikan tertentu menunjukkan hasil angka putus sekolah atau yang tidak melanjutkan Pendidikan relative besar. Dalam artikelnya Sirojjuddin (2020) mengatakan bahwa sekitar $45,13 \%$ siswa di Papua Barat tidak bisa membaca untuk itulah pendidikan di Papua Barat khususnya kota Sorong masih perlu diberikan perhatian lebih dari pemerintah.

Kota Sorong merupakan pintu masuk perekonomian di Papua Barat memiliki peranan penting untuk kemajuan di Papua Barat selain ibu kota Provinsi Manokwari. Peranan yang begitu besar tidak akan mudah dijalankan bila masih banyak anak - anak yang belum bersekolah. Keadaan ini paling banyak dialami oleh masyarakat yang bermukim di wilayah pesisir kota Sorong. Salah satu kelurahan yang berada di daerah pesisir kota Sorong adalah kelurahan Suprau Distrik Maladum Mes. Kelurahan ini hingga tahun 2017 hanya terdapat 1 unit Paud, 1 unit SD dan 1 unit SMP dan 1 Unit Perguruan Tinggi. Sementara untuk 
jumlah Taman Kanak - kanak baik negeri maupun swasta di kelurahan Suprau Distrik Maladum Mes sendiri tidak tersedia, dan bahkan untuk kelurahan - kelurahan lainnya yang masih terdapat dalam distrik Maladum Mes.

Tabel 1. Jumlah Taman Kanak-kanak (TK) Negeri dan Swasta per Kelurahan di Distrik Maladum Mes, Tahun 2017

\begin{tabular}{lll}
\hline \multirow{2}{*}{ Kelurahan } & Jumlah Sekolah & \\
\cline { 2 - 3 } & TK Negeri & TK Swasta \\
\hline Saoka & - & - \\
Tanjung Kasuari & - & - \\
Suprau & - & - \\
Tampa Garam & - & - \\
\hline
\end{tabular}

Sumber: kelurahan se-Maladum Mes

Berdasarkan data di atas jelas telihat bahwa di distrik Maladum Mes pada umumnya dan kelurahan Suprau khususnya tidak memiliki tempat belajar bagi anak usia $4-6$ tahun. Walaupun jelas dikatakan dalam data yang ada setiap kelurahan memiliki sekolah namun tidak untuk jenjang pendidikan sekolah Taman Kanak - kanak. Widuroyekti (2019) mengatakan bahwa taman Kanak - kanak merupakan pendidikan awal untuk pengembangan kemampuan literasi anak, karena di sini anak akan diberikan kegiatan menstimulasi perkembangan kemampuan mendengar, berbicara, membaca dan menulis. Sejatinya pengembangan kemampuan anak di Taman Kanak - kanak berupa pengembangan sikap dan perilaku serta kemampuan aspek dasar yang berupa pengembangan aspek bahasa, daya pikir, daya cipta, jasmani dan juga ketrampilan. Yus (2015) Sehingga dapat dikatakan bahwa seorang anak yang melewati Pendidikan di Taman Kanak - kanak akan memiliki perkembangan kemampuan literasi, perkembangan dalam sikap dan perilaku, juga kemampuan lainnya yang mendukung perkembangan anak tersebut.

Selain itu Taman Kanak-kanak merupakan bagian Pendidikan yang mengembangkan seluruh aspek pengembangan anak. Pernyataan ini sejalan dengan pendapat dari Yosmelia (2020) yang mengatakan bahwa TK merupakan salah satu pendidikan yang mengembangkan aspek pengembangan anak meliputi aspek perilaku, aspek fisik motorik, aspek kognitif, aspek seni, dan juga bahasa. Dimana setiap aspek yang ada harus dikembangkan dengan baik dan juga sesuai dengan tahap perkembangan usia anak.

Berdasarkan hasil survey dan hasil wawancara dengan kepala kelurahan Suprau diperoleh informasi bahwa walaupun tidak memiliki taman kanak - kanak namun kelurahan Suprau telah memiliki rumah baca, hanya saja efektifitas penggunaan rumah baca ini masih sangatlah kurang sementara banyak anak yang berusia $4-6$ tahun di kelurahan suprau ini. Salah satu factor yang menghambat kurangnya penggunaan rumah baca ini adalah minimnya tenaga pengajar. Sehingga permasalahan yang dimiliki oleh mitra saat ini adalah bagaimana mitra meningkatkan literasi baca dan tulis bagi anak - anak usia $4-6$ tahun. Sehingga berdasarkan permasalahan yang dimiliki oleh mitra maka kegiatan pengabdian ini dilakukan dengan tujuan untuk meningkatkan literasi baca tulis anak usia sekolah di kelurahan Suprau distrik Maladum Mes 


\section{METODE}

Pengabdian yang dilakukan di Kelurahan Suprau Distrik Maladum Mes dilaksanakan pada bulan Maret - Juni 2020. Adapun metode pelaksanaan yang dilakukan dalam pengabdian ini berupa metode observasi, sosialisasi, dan pendampingan dan evaluasi.

Kegiatan program pengabdian kepada masyarakat diawali dengan melakukan survey di kelurahan suprau distrik Maladum Mes pada tanggal 6-7 maret tahun 2020. Survey dilakukan dengan maksud agar program yang telah disusun lebih dimantapkan persiapanya dalam hal persiapan media pembelajaran bagi anak - anak. Lebih lanjut dari program ini tim yang akan melaksanakan pengabdian ini berdiskusi lebih lanjut dengan kepala kelurahan suprau untuk memperoleh jumlah atau data lengkap anak - anak yang masih buta aksara. Dari hasil diskusi diperoleh data jumlah anak yang masih belum dapat melakukan baca dan tulis sebanyak 25 orang anak.

Selanjutnya untuk memperoleh hasil dan luaran yang diinginkan dari program pelaksanaan pengabdian ini, sebelum terjun langsung pada program yang ada, maka mahasiswa yang telah dipilih akan diberikan pembekalan dari tim dosen. Pembekalan tersebut berupa pelatihan literasi dan pelatihan cara mengajar yang baik bagi anak - anak. Setelah itu, dosen dan mahasiswa mempersiapkan media - media pembelajaran yang akan digunakan selama pengabdian.

Setelah melakukan persiapan pengabdian, maka tim terjun langsung ke lapangan untuk memberikan sosialisasi bagi orang tua anak yang akan di berikan pendampingan membaca dan menulis. Hal ini dilakukan dengan maksud agar orang tua anak mengetahui program ini dan keuntungan - keuntungan yang akan diperoleh selama program pengabdian ini dilakukan. Dan hal ini disambut baik oleh para orang tua dan orang tuapun memberikan dukungan bagi tim yang akan melakukan pengabdian.

Pelaksanaan program literasi baca tulis dilaksanakan sesuai dengan jadwal yang telah ditentukan dengan lokasi rumah baca dan lingkungan sekitar. Program pendampingan ini dilakukan selama pandemic covid - 19 namun peserta atau anak - anak yang mengikuti kegiatan dibatasi setiap harinya, sehingga 1 orang anak dapat mengikuti program pendampingan 3 hari dalam 1 minggu.

Metode pendampingan digunakan dalam pengabdian kali ini untuk melakukan pendampingan secara langsung dalam proses baca dan tulis. Proses ini memanfaatkan berbagai media dan juga teknologi yang ada dalam proses belajar mengajar. Untuk memberikan keleluasaan belajar sambil bermain pada anak - anak maka proses pelaksanaan belajar dan mengajar tidak hanya dilakukan di dalam rumah baca namun juga di luar ruangan seperti di daerah pesisir pantai.

Kegiatan ini dilakukan dengan memberikan pembelajaran seperti taman kanak - kanak, dimana anak - anak akan diajarkan cara membaca yang baik dan benar. Pada saat ini anak akan diajarkan mengenali kata dengan media gambar, atau barang yang ada di sekitarnya, bahkan dengan menggunakan pengalaman - pengalaman anak saat berada di lingkungannya. Disini anak juga akan diajarkan mengeja kata - kata baru agar anak dapat menggabungkan suku kata menjadi kata. Hal ini dilakukan karena pemahaman anak akan lebih baik bila diawali dengan pengetahuannya saat berbicara pengalaman di lingkingan sekitar. Karena dengan jalan ini anak akan lebih didekatkan pada situasi nyata dan bermakna dalam kehidupannya. (Andi. 2019)

Kegiatan pengabdian ini melibatkan beberapa mahasiswa sehingga proses pengabdian direncanakan akan dilakukan sesuai dengan jadwal yang telah diatur. Kegiatan pendampingan dilakukan pada saat pagi hari dimulai pukul 08.00 - 10. 00 WIT dari senin hingga jumat. Masing - masing pendamping akan dibantu oleh dua - tiga orang mahasiswa dan diberikan 
jadwal secara bergantian. Selama mulai diterapkannya masa PSBB, maka jadwal pendampingan tetap dilakukan dengan menerapkan protocol Covid-19.

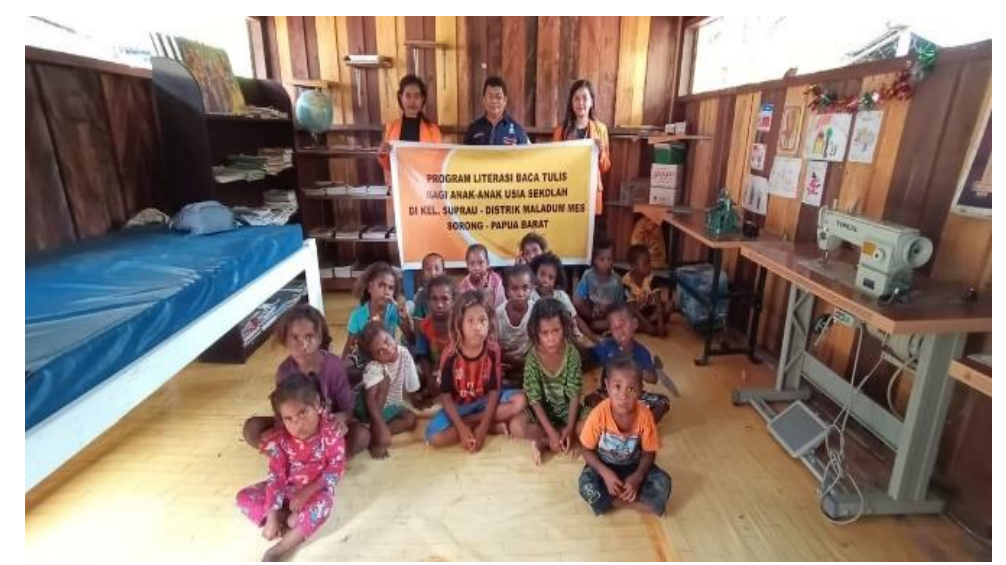

Gambar 1. Peserta pendampingan literasi baca tulis

HASIL

Program pengabdian literasi baca tulis yang dilakukan selama 3 bulan yang dilakukan di kelurahan Suprau distrik Maladum Mes dilakukan dengan melihat kondisi awal kemampuan baca dan tulis dari anak - anak usia sekolah.

Pada bulan pertama sebanyak 25 orang anak berusia $4-6$ tahun mulai diberikan pendampingan dalam membaca, lewat proses bimbingan mengenal huruf hingga mengeja. Proses pendampingan dilakukan tidak hanya di dalam ruangan namun juga di luar ruangan agar anak dapat belajar sambil bermain.

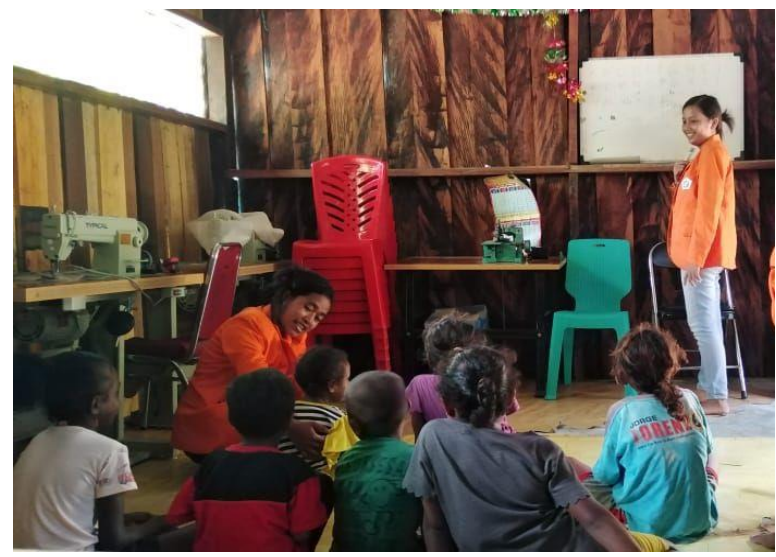

Gambar 2. Proses belajar membaca sambil bermain rumah baca

Untuk melihat hasil pendampingan membaca yang telah dilakukan selama 1 bulan, maka tim melakukan evaluasi untuk melihat kemajuan yang dihasilkan selama pendampingan literasi baca. Evaluasi dilakukan agar dapat melihat efektivitas metode yang digunakan selama pengabdian. Berdasarkan hasil evaluasi diperoleh hasil seperti yang ditampilkan dalam gambar 3. 


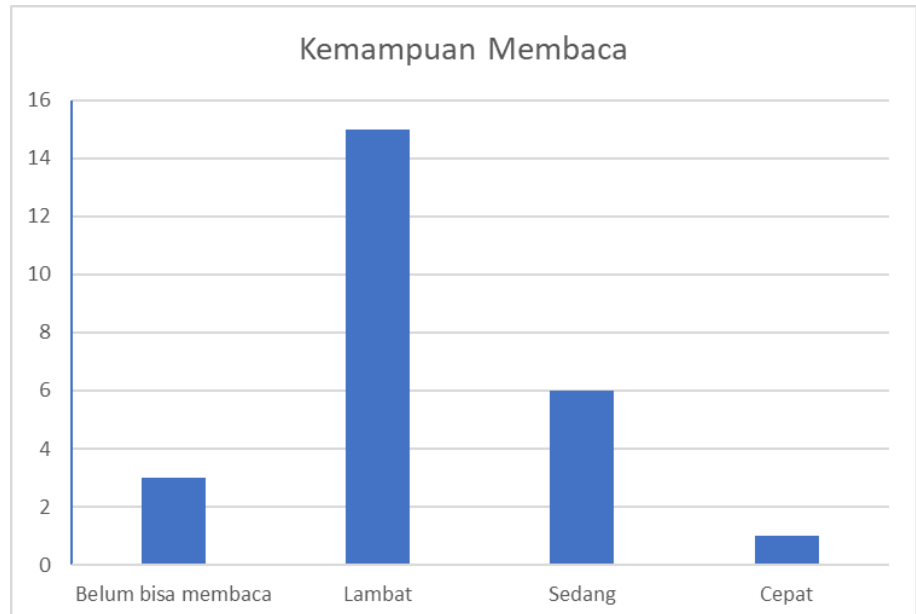

Grafik 1. Hasil evaluasi Pendampingan Membaca Selama 1 Bulan

Berdasarkan hasil evaluasi pendampingan yang telah dilakukan maka terlihat bahwa adanya kemajuan membaca dari anak - anak tersebut. Sehingga proses pembelajaran dengan metode yang sama terus dilakukan hingga anak dapat membaca bacaan sedang hingga cepat. Kegiatan yang akan dilakukan pada tahap ini adalah dengan memberikan buku - buku bacaan bergambar yang menarik yang ada pada rumah baca kepada anak, pada saat ini juga media yang telah dipersiapkan sebelumnya berupa permainan - permainan kata seperti susun kata, tebak kata dan tebak huruf diberikan kepada anak, dalam permainan ini anak akan diberikan pemahaman lebih kepada anak agar dapat memahami apa yang di baca.

Berdasarkan hasil evaluasi yang telah dilakukan maka tim selanjutnya memasukan kegiatan belajar menulis karena terlihat anak telah mampu untuk membaca walaupun masih dalam kategori sedang dan lambat. Disini anak- anak mulai diajarkan agar mampu untuk menulis kata demi kata sesuai dengan ejaan mereka.

Setelah dilakukannya evaluasi maka proses pendampingan literasi baca tulis tetap berlanjut dan pada bulan ke 2 anak mulai diajarkan untuk menulis. Hal ini dilakukan karena melihat hasil evaluasi pertama yang menunjukkan sebagian besar anak telah mampu untuk membaca, dengan arti mereka telah mengenal huruf dan mengeja dengan baik. Kegiatan pendampingan literasi baca dan tulis dilakukan kembali selama 1 bulan kedepan dan pada akhir bulan berjalan tim melakukan evaluasi kedua untuk membaca dan menulis pada anak - anak.

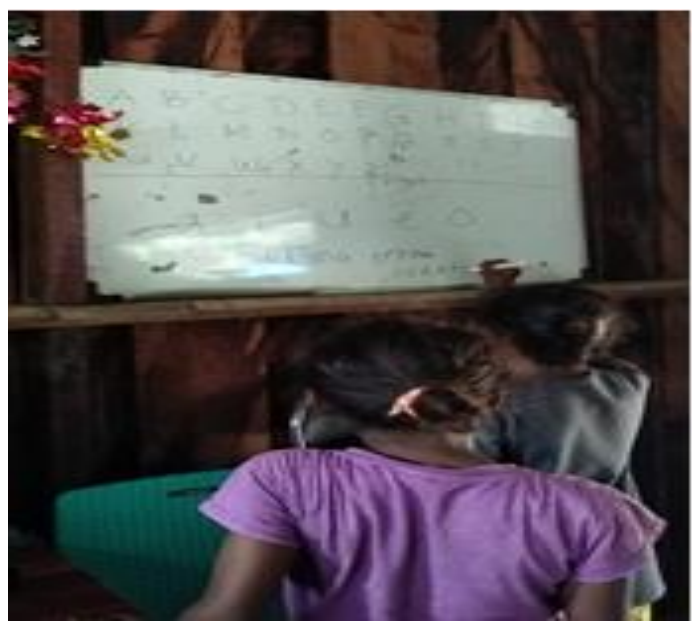

Gambar 3. Proses Belajar Menulis Pada Anak 
Evaluasi kembali dilakukan oleh tim setelah proses pendampingan pada akhir bulan kedua. Hasil evaluasi untuk hasil membaca disajikan dalam gambar 5.

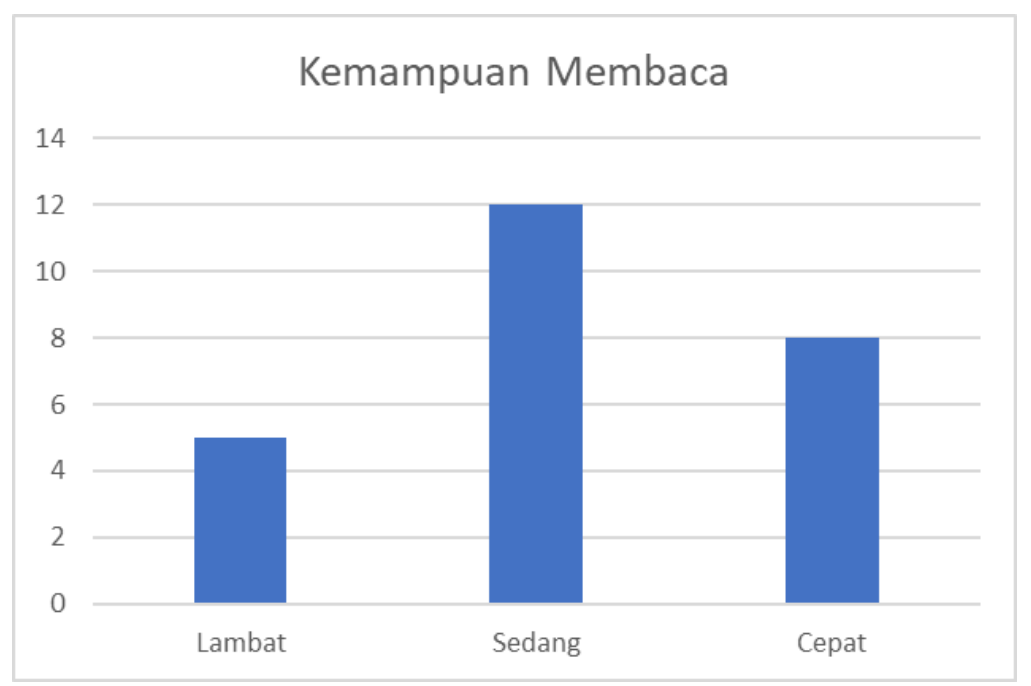

Grafik 2. Hasil evaluasi Pendampingan Membaca Selama 2 Bulan

Dari gambar 5 di atas terlihat bahwa selama 2 bulan proses pendampingan membaca, hasil yang diperoleh anak - anak kelurahan Suprau menjadi bisa membaca walaupun masih terdapat 5 orang anak yang masih lambat membaca. Namun hasil ini menunjukkan adanya peningkatan membaca anak selama 2 bulan berjalan. Sementara itu, pada saat yang sama juga dilakukan evaluasi kemampuan menulis anak. Hasil evaluasi menulis disajikan dalam gambar 6.

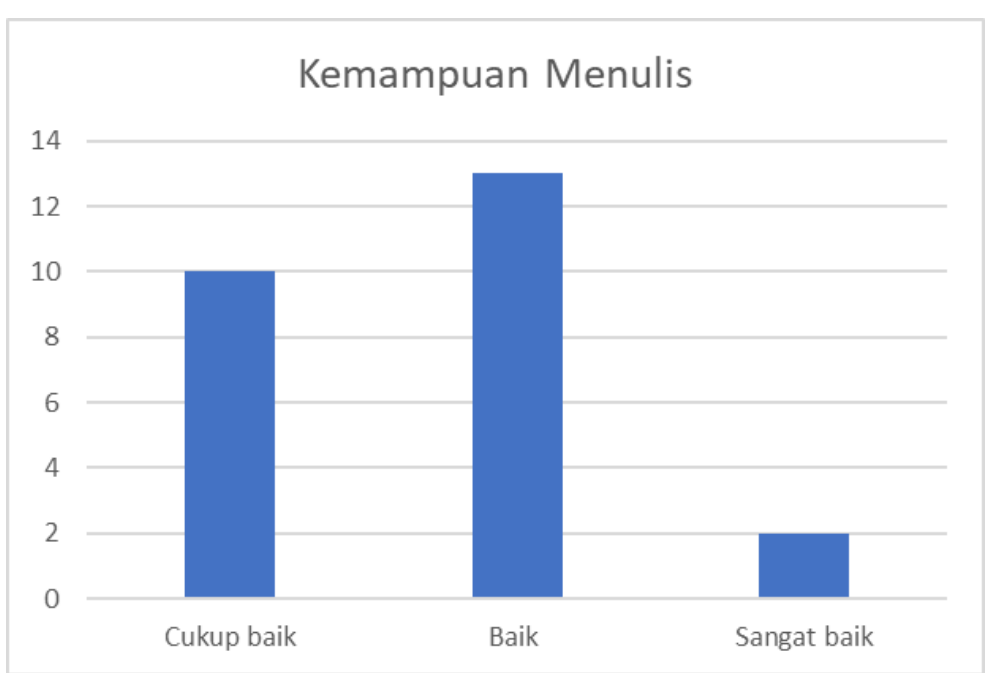

Grafik 3. Hasil evaluasi Pendampingan Menulis Selama 1 Bulan

Berdasarkan hasil pendampingan menulis yang baru dilakukan selama 1 bulan terlihat hasil yang cukup baik. Dimana dari 25 anak yang diberikan pendampingan menulis terdapat 10 orang anak yang mampu menulis dengan cukup baik yang berarti anak telah bisa menulis namun masih lambat dan belum rapi. Selanjutnya 13 anak mampu menulis dengan baik yang berarti anak bisa menulis dan tulisan anak mulai rapi. Sementara sisanya 2 orang anak mendapatkan penilaian sangat baik, karena telah mampu menulis dengan cepat dan rapi. Program terus dilanjutkan selama 1 bulan ke depan hingga anak berhasil membaca bacaan dengan relative cepat dan anak mampu menulis dengan baik. 


\section{PEMBAHASAN}

Ketidaktersediaannya sekolah taman kanak - kanak di kelurahan Suprau menyebabkan anak anak usia sekolah hanya bermain di rumah tanpa diberikan pendidikan yang sesuai sebelum masuk ke jenjang Sekolah Dasar. Padahal pendidikan taman kanak - kanak adalah suatu wadah yang sangat diperlukan untuk mempersiapkan sosial emosional dan kognitif bahasa anak. Hal ini sesuai dengan hasil penelitian Mashfufah, dkk (2019) yang menyatakan bahwa kesiapan aspek sosial emosional lebih penting dibandingkan dengan aspek kognitif. Seorang anak yang memiliki aspek sosial emosional yang baik akan dapat mengontrol diri dan sadar akan kebutuhannya, selain itu anak akan memiliki kepercayaan diri yang jauh lebih baik dan hadirnya motivasi dalam diri anak untuk menyelesaikan tugas - tugas yang ada. Seorang anak yang memiliki kesiapan aspek kognitif maka anak akan memiliki dasar - dasar menulis dan membaca dasar yang baik.

Pada umumnya anak yang memasuki jenjang sekolah dasar adalah anak yang harus mengenal huruf dan angka, memiliki kemampuan menulis walaupun hanya berupa menulis dasar. Hal ini tidak akan dimiliki oleh anak - anak di kelurahan Suprau sehingga dapat dipastikan pada usia Sekolah Dasar mereka belum mampu untuk membaca dan menulis. Hadirnya rumah baca yang disediakan oleh pemerintahpun tidak dimanfaatkan dengan baik karena kurangnya sumber daya manusia.

Hasil evaluasi pertama dan kedua memberikan hasil yang terbilang baik, Terlebih untuk hasil evaluasi kedua, hal ini terjadi karena adanya penggunaan metode permaianan dalam upaya peningkatan literasi baca dan tulis memperoleh peningkatan untuk setiap evaluasi. Hasil pengabdian ini sejalan dengan pernyataan Yosemelia (2020) dalam penelitiannya yang menuliskan bahwa kemampuan untuk mengenal kata dalam bentuk pemainan dan menggunakan media yang bervariasi serta menarik akan membuat anak menjadi tidak bosan dan tidak kesulitasn sehingga anak akan mampu untuk meningkatkan kemampuan mereka dalam mengenal kata.

Luaran yang diperoleh dari kegiatan pengabdian ini adalah peningkatan daya saing belajar dan keilmuan bagi anak - anak di suprau, dalam hal ini peningkatan dalam membaca dan menulis sehingga berbagai bacaan yang telah tersedia di rumah baca dapat menjadi pengetahuan baru bagi anak - anak, selain itu anak - anak telah memiliki dasar yang baik sebelum mereka memasuki jenjang sekolah dasar.

\section{KESIMPULAN}

Pengabdian kepada masyarakat dengan program Peningkatan Kemampuan Literasi Baca Tulis Bagi Anak - Anak Usia Sekolah di Kelurahan Suprau Distrik Maladum Mes diperoleh kesimpulan: Terjadi peningkatan kemampuan membaca dan kemampuan menulis dengan baik. Harapan kami kedepannya kegiatan ini bukan hanya untuk 1 kelurahan saja namun dapat mencakup semua kelurahan yang ada di distrik Maladum Mes.

\section{ACKNOWLEDGEMENT}

Ucapan terima kasih kami haturkan kepada Pimpinan Politeknik Saint Paul Sorong yang telah memberikan bantuan kontribusi pendanaan pengabdian yang kami lakukan di Distrik Maladum Mes. 


\section{DAFTAR RUJUKAN}

Ahmadi, F., Ibda Hamidulloh. (2018). Media Literasi Sekolah (Teori dan Praktik). Semarang: Pilar Nusantara.

Andi, A. S. N., Nggaruaka, T., \& Hermansyah, A. K. (2019). PEMBUATAN MEDIA PEMBELAJARAN BACA TULIS HITUNG (CALISTUNG) BAGI MASYARAKAT DI DISTRIK ULILIN. Sarwahita, 16(02), 105-115.

Badan Pusat Statistik. (2020). Kecamatan Maladomes Dalam Angka 2018. Sorong: BPS Kota Sorong

Badan Pusat Statistik. (2020). Statistik Kota Sorong. Sorong: BPS Kota Sorong

Ishak, I., \& Mulyanah, E. Y. (2020). Pelatihan Guru SD di Tangerang: Implementasi TPR dalam Meningkatkan Penguasaan Bahasa Inggris. Dinamisia: Jurnal Pengabdian Kepada Masyarakat, 4(1).

Mashfufah, S. R., Rudiyanto, R., \& Listiana, A. (2020). PERSEPSI GURU TAMAN KANAKKANAK (TK) TERHADAP KEMAMPUAN PERKEMBANGAN KOGNITIF BAHASA SEBAGAI ASPEK PENTING DALAM KESIAPAN BERSEKOLAH ANAK (SCHOOL READINESS). Edusentris, 6(3), 130-138.

Nggaruaka, T. (2017). Peningkatan Kemampuan Menulis Teks Deskripsi dengan Menggunakan Teknik Retrival Jaringan Semantik Siswa Kelas VII SMP Negeri I Kabupaten Merauke Provinsi Papua. SKRIPSI Jurusan Sastra Indonesia-Fakultas Sastra UM.

Sirojjuddin, S., Hafid, A., \& Mursalim, M. (2020). PENDAMPINGAN LITERASI MELALUI PROGRAM PENGUATAN BACA TULIS KELAS AWAL WILAYAH PINGGIRAN DAN TERPENCIL. Jurnal Abdimasa, 3(1), 1-5.

Widuroyekti, B., Sambada, D., \& Prastiti, T. D. BERBASIS PENDIDIKAN KARAKTER DI TAMAN KANAK-KANAK.

Widyastuti, Anna. 2017. Kiat Jitu Anak Gemar Baca Tulis. Jakarta: PT. Alex Media Komputindo

Yus, A. (2015). Penilaian perkembangan belajar anak taman kanak-kanak. Kencana.

Yosmelia, Y., \& Aulia, P. (2020). Meningkatkan Kemampuan Mengenal Kata Melalui Permainan Kartu Kata Bergambar Berbentuk Jendela di Taman Kanak-Kanak Negeri Pembina Lubuk Begalung Padang. JFACE: Journal of Family, Adult, and Early Childhood Education, 2(3), 270-276. 